\title{
The Effectiveness of Integral Urban Strategies: Policy Theory and Target Scale. The European URBAN I Initiative and Employment
}

\author{
Clemente J. Navarro-Yáñez
}

check for updates

Citation: Navarro-Yáñez, C.J. The Effectiveness of Integral Urban Strategies: Policy Theory and Target Scale. The European URBAN I Initiative and Employment. Sustainability 2021, 13, 6251. https:// doi.org/10.3390/su13116251

Academic Editor: Edwin H. W. Chan

Received: 13 April 2021

Accepted: 25 May 2021

Published: 1 June 2021

Publisher's Note: MDPI stays neutral with regard to jurisdictional claims in published maps and institutional affiliations.

Copyright: (C) 2021 by the author. Licensee MDPI, Basel, Switzerland. This article is an open access article distributed under the terms and conditions of the Creative Commons Attribution (CC BY) license (https:/ / creativecommons.org/licenses/by/ $4.0 /)$.
Centre for Sociology and Urban Policies-The Urban Governance Lab, Pablo de Olavide University, 41013 Seville, Spain; cnavyan@upo.es

\begin{abstract}
Integrated urban development strategies are shaping a new policy frame to cope with the complexity of urban problems. This implies multi-level policy mixes involving multiple goals, the collaboration between different actors, and policy theories based on complementarity between different policy tools (and their causal processes). As in other policies, the third aspect has been less analysed. This article studied the theory behind policy mixes developed in the European Union URBAN I Initiative framework and the effects on its employment inclusion goal. The policy theory suggests complementary effects between policy actions oriented toward economic activities and those oriented at increasing employment skills to, in turn, increase residents' inclusion in the labour market. The quasi-experimental approach applied at the neighbourhood level in Spain showed a moderate influence on employment among the youngest age cohorts and a more evident impact on business density. Nevertheless, evidence concerning the complementarity between actions oriented at improving labour market demand and labour market supply in targeted neighbourhoods suggested in the program theory is less convincing. This exercise showed the methodological challenges in assessing the effectiveness of integral urban initiatives and offered some suggestions regarding the policy theory behind them through a European Union case.
\end{abstract}

Keywords: integral policy strategies; urban policy; policy mixes; evaluation; quasi-experimental design; European Union

\section{Introduction}

There is a growing consensus on the nature of urban problems as complex issues, as their causes and effects cross-cut different policy sectors or sub-systems. Therefore, as with other policies with cross-cutting issues, urban policies tend to be developed by applying integral policy strategies (IPSs) to address the adverse effects of fragmented government, with sectoral policy actions to deal with complex policy problems. These strategies aim to shape a new policy sub-system to include the objectives, actors, and instruments characteristic of existing sectoral sub-systems-policy sectors concerned with the complex problem [1].

Therefore, integral urban policies imply a multi-goal agenda, collaboration among different sectoral actors, and an intervention logic that tries to combine policy instruments from different policy sectors to improve an urban space. This intervention logic means each integral urban initiative or policy proposes a specific policy theory linking objectives and expected results through specific causal processes and complementarities between them $[2,3]$. In addition to appropriated research strategies, to evaluate its effectiveness, the policy theory in each case should be studied because it establishes the main hypotheses to be assessed [4].

Since the 1990s, the EU has promoted initiatives based on integral policy strategies to address urban problems. This article analysed the effectiveness of the URBAN I Initiative (1994-1999), particularly concerning its objective to improve employment inclusion in 
targeted neighbourhoods. The policy theory behind this program is based on the classic combination between policy actions on labour market supply and demand sides (employability training and increasing labour opportunities by supporting economic activity). However, implicitly, the theory also includes two premises that could reduce the effectiveness of such complementarity. On the one hand, more employment opportunities would increase residents' employment inclusion if the professional skills they acquire are in line with those required by the new economic activities in the neighbourhood. However, projects do not set out mechanisms to ensure this match. On the other hand, the urban processes that the policy tries to modify (job seeking and business decisions on location) occur on a grander urban scale than targeted neighbourhoods, promoting spillover or displacement effects. Improvements in residents' employment inclusion could therefore arise due to improvements in their occupational skills, but without the complementarity promoted by the economic activity increase underlying the programme's policy theory regarding this objective.

After this introduction, the Section 2 is devoted to describing the meaning of IPSs as a new approach or policy frame for sustainable urban development policies. The Section 3 shows the main traits of the urban dimension of European Union policies as an example of IPSs in urban policies. The Section 4 presents the research strategy applied to analyse the effectiveness of URBAN I Initiative: the analysis of policy theory regarding the employment objective to establish causal processes to be assessed and the quasi-experimental design used to show program effects. The Section 5 presents and discusses empirical results. The conclusion section summarises the main results and research limitations, suggesting the importance of improving data and research strategies, and, above all, of analysing the policy theory behind the intervention logic of integral urban policies to understand its effects and improve its design.

\section{Toward a New Policy Frame for Urban Policies: Sustainable Development and Policy Integration}

The idea of integral policies to cope with the complexity of urban issues and the common fragmented sectoral approach to them is shaping a new policy frame for urban policies based on the idea of sustainable development and policy integration. As policy frame, establishes a policy rationale, general problems to solve, overall goals and implementation preferences $[5,6]$. It has its roots in the previous place-based initiatives and programs launched in European countries, the United States, and other regions. They aim to promote revitalisation in disadvantaged neighbourhoods, combining policy actions for urban space, social integration, and economic development $[7,8]$. Nowadays, these initiatives include other goals linked to climate change and environmental sustainability, as well as broader urban scales promoting the idea of sustainable urban development. This is mostly due to the support of international agencies, for example, the New Urban Agenda and the Sustainable Development Objectives promoted by the UN [9].

From an analytical point of view, this new policy frame means that urban policies comprise multi-level policy mixes. Sustainable urban development policies include goals from different policy sectors, the collaboration of public and private actors from different policy sectors and scales, and the combination of different policy instruments. They are applied simultaneously in different territories through top-down projects designed by local authorities in the framework of supra-local programs and policies. Therefore, this new frame involves integration processes in both the substantive dimension (goals) and the procedural dimension (actors and instruments) of public policies (Table 1) [3]. 
Table 1. Urban integral policy strategies as multi-level policy mixes: main dimensions.

\begin{tabular}{ccr}
\hline Policy Dimension & Policy Integration & Policy Integration Means \\
\hline $\begin{array}{c}\text { Substantive } \\
\text { (goals) }\end{array}$ & Comprehensiveness of goals & A holistic (shared) conception of problems and goals across policy sectors \\
\hline $\begin{array}{c}\text { Procedural } \\
\text { (means) }\end{array}$ & Place-based orientation & Territorial targets according to problems and goals established \\
\hline & Multi-level governance & Collaboration between actors across policy sectors and administrative levels \\
\hline
\end{tabular}

With regard to the substantive dimension, policy integration involves developing a shared vision of the problems to be solved and the goals to be pursued between policy sub-systems concerned with policy issues that need to be addressed. In this regard, the idea of sustainable urban development is becoming the general reference framework for setting the goals of urban policies worldwide. This approach implies a comprehensive vision about urban development goals to promote a balanced improvement in environmental sustainability, economic development, and social inclusion $[10,11]$. Therefore, urban policies adopt the character of multi-objective strategies to cope with the complexity of urban problems.

This policy frame also means urban policies are understood as place-based policies oriented towards a specific socio-spatial context $[12,13]$. Therefore, the substantive dimension also implies the specification of territorial targets according to the policy goals pursued, e.g., classical integral urban regeneration policies focused on disadvantaged neighbourhoods, economic recovery policies focused on urban spaces in economic decline, and place-based policies used to include eligibility criteria to select appropriate territorial targets [14-16].

With regard to the procedural dimension, IPSs concern at least two issues: multi-level governance and policy instruments defining the policy intervention logic $[17,18]$. In the first case, IPSs involve collaborative processes and coordination between actors in the policy sectors involved. Each policy sector defines a specific policy domain in which different types of public and private actors from different scales participate and collaborate [19]. The traditional distinction between economic development and redistributive urban policies promotes different policy domains and their specific governing coalitions: the well-known pro-growth and progressive coalitions. However, other more cross-cutting policies-such as urban regeneration initiatives-promote hybrid governing coalitions integrating these two policy domains $[20,21]$. In this regard, policy integration studies analyse the institutional processes and changes made to ensure joint action among different policy sub-systems from informal collaborations to specific formal governance bodies [1].

The intervention logic means there is an interdependency between instruments or policy tools used to achieve proposed goals. Policy tools included in urban policy mixes aim to produce specific causal processes to give rise to the behaviours or situations necessary to fulfil the proposed goals [3]. From this perspective, policy integration implies interdependent relationships between such causal processes, both for a specific objective and between them, since the outcomes of some actions may affect the causal processes of other policy actions and their outcomes. Therefore, the study of the integral intervention logic focuses on the policy theory underlying each policy mix, the causal processes behind their policy actions, and their consistency-as the mutual support between them-to achieve the proposed outcomes $[2,4]$.

These analytical dimensions can be a reference framework for analysing whether urban policies-as multi-level complex policy mixes-produce policy integration processes and examine IPSs effectiveness. Nevertheless, from an analytical point of view, these are different dimensions that can reach a higher or lower level of policy integration in each case and may or may not be related to each other [22]. The first two have received more attention when analysing the transversality of goals or institutional changes to promote the 
coordination of sub-systems. By contrast, there have been few analyses of the intervention logic, the specific policy theory behind integral urban policies analysed, and there is little evidence concerning its effectiveness or impacts [23].

\section{The Policy Frame of European Union Urban Initiatives: Sustainable Urban Development through Integral Policy Strategies}

Since the 1990s, the EU has promoted integral policy strategies to address urban problems. From the original URBAN Initiative in the 1990s centred on integral urban regeneration to current sustainable urban development initiatives in the European Regional Development Fund (ERDF) framework during the 2014-2020 programming period, policy integration has become mainstream for the urban dimension of the European Cohesion Policy [24]. These initiatives applied policy integration regarding goals, actors, and policy instruments defining complex multi-level policy mixes implemented through local projects (Table 2) [3,25].

Table 2. The general policy frame of EU urban initiatives: sustainable urban development through integral policy strategies.

\begin{tabular}{|c|c|c|c|}
\hline \multirow[b]{2}{*}{ Policy Dimension } & \multirow[b]{2}{*}{ Policy Integration } & \multicolumn{2}{|r|}{ Period } \\
\hline & & $\begin{array}{c}\text { 1990-2006 } \\
\text { Integral Urban Regeneration }\end{array}$ & $\begin{array}{c}2007-2020 \\
\text { Integral Sustainable Urban } \\
\text { Development }\end{array}$ \\
\hline \multirow[t]{2}{*}{$\begin{array}{l}\text { Substantive } \\
\text { (goals) }\end{array}$} & Comprehensiveness of goals & $\begin{array}{l}\text { Physical space } \\
\text { Economic development } \\
\text { Social inclusion } \\
\text { Governance } \\
\text { Environment protection }\end{array}$ & $\begin{array}{c}\text { Physical space } \\
\text { Economic development } \\
\text { Social inclusion } \\
\text { Governance } \\
\text { Climate change and environmental } \\
\text { sustainability }\end{array}$ \\
\hline & Territorial target & $\begin{array}{c}\text { Disadvantaged } \\
\text { neighbourhoods in cities }\end{array}$ & $\begin{array}{l}\text { Urban areas with specific problems at } \\
\text { different scales (neighbourhoods, } \\
\text { municipalities, urban functional areas) }\end{array}$ \\
\hline \multirow[t]{2}{*}{$\begin{array}{l}\text { Procedural } \\
\text { (means) }\end{array}$} & $\begin{array}{l}\text { Multi-level governance, as } \\
\text { collaborations between }\end{array}$ & $\begin{array}{l}\text { government levels } \\
\text { sectorial policy sub-systems } \\
\text { public participation }\end{array}$ & $\begin{array}{l}\text { government levels } \\
\text { sectorial policy sub-systems } \\
\text { public participation } \\
\text { neighbouring municipalities }\end{array}$ \\
\hline & $\begin{array}{c}\text { Intervention logic, } \\
\text { complementarity between }\end{array}$ & $\begin{array}{l}\text { policy tools and their causal } \\
\text { processes }\end{array}$ & policy tools and their causal processes \\
\hline
\end{tabular}

First, in the European Cohesion Policy framework, urban initiatives should promote territorial cohesion and sustainable urban development, which is understood as a combination of improvements in physical space, and economic, social, environmental, and governance objectives to enable more intelligent, inclusive, and sustainable cities [26,27]. Before the 2007-2014 programming period, URBAN I and URBAN II Initiatives established goals and actions across different policy sectors that local projects could include in their policy mixes to promote social-spatial cohesion [28,29]. Since 2007, urban initiatives have been included in the framework of EDRF. Local projects can decide goals across thematic priorities established by the EU Cohesion Policy under those specified in their national or regional operational plans [24].

Second, in former URBAN Initiatives, the territorial targets were mainly disadvantaged urban areas in major cities. Since 2007, this has also applied to infra-municipal areas with specific problems or functional urban areas, the EU proxy for metropolitan areas that integrates neighbouring municipalities [25,30]. Therefore, territorial targets have changed in nature and scale, including urban realities different from disadvantaged neighbourhoods in large cities.

Third, urban initiatives should be planned and implemented through multi-level governance processes. These processes imply vertical policy integration (different adminis- 
trative levels and local actors), horizontal policy integration (different policy sub-systems), the active involvement of local actors [31], and, more recently, territorial cooperation between neighbouring municipalities due to the incorporation of functional urban areas as territorial targets together with the previous focus on the neighbourhood scale.

Fourth, local projects should combine different policy instruments, promoting interdependences between them in order to attain their multi-objective agenda [32]. Based on experiences of URBAN Initiatives, integral urban development means complementation between the different policy tools-and their causal processes-included in local policy mixes to promote socio-spatial cohesion, for example, the combination of investment in physical infrastructures and human capital [33].

EU urban initiatives thus exemplify the new policy frame for urban policies oriented toward sustainable urban development through integral policy strategies. Nevertheless, as in the analysis of other policies, the study of the policy theory defining the intervention logic behind policy mixes has received less attention than the analysis of the comprehensiveness of goals or their collaborative processes. Academic studies and evaluations made by the European Commission have shown the transversality between different objectives, i.e., the existence of collaboration processes or the promotion of specific bodies to ensure coordination among administrative levels and policy sub-systems [34-36]. Nevertheless, interdependences between policy tools and the causal processes included in local policy mixes-and their efficiency and impacts on the expected outcomes-have received less attention [33].

This article analysed the issues with regard to one of the main objectives of urban initiatives promoted by the EU: to increase employment among residents in targeted territorial areas. In addition to the common methodological difficulties of attributing causality to urban policies [37], the evaluation of integral strategies is even more challenging due to the number and complexity of the causal processes involved [38]. For this reason, our focus was on a concrete expected result and the causal processes associated with it in a specific program: the URBAN I Initiative in Spain.

\section{Cases, Program Theory, and Methods: URBAN I and Employment in Spain}

The URBAN I Initiative was implemented in 118 local initiatives across the EU between 1994 and 1999. In its general policy frame oriented toward integral urban regeneration, municipalities were to develop a project applying an integral perspective to increase social cohesion in disadvantaged neighbourhoods of large cities. Around 25 percent of these projects were implemented in Spanish cities using a broad, integrated approach adjusted to the European Commission's guidelines, including physical infrastructure, support to small and medium enterprises and social inclusion actions [34].

To evaluate the impact of this program on employment, two main tasks were developed with the aim of reducing the classical attribution gap in urban policy evaluation [37]. First, based on program documentation and analyses of local portfolios, we studied the program theory to understand how it tried to link goals and outcomes through policy tools and their causal process [4]. The objective was to determine the main causal processes in policy tools and their complementarities to increase employment among residents to establish the hypotheses to be analysed. Second, a quasi-experimental design was applied, comparing changes between targeted and non-targeted urban areas before and after program implementation (a pre-post intervention with control group design). This section is devoted to explaining these two tasks.

4.1. URBAN I and the Integral Strategy Concerning Employment: Analysing Causal Processes in the Program Policy Theory

In Spain, 29 cities of up to 100,000 inhabitants implemented the URBAN I Initiative (1994-1999) in disadvantaged neighbourhoods. Within the framework provided by this EU program, their objectives focused on five main goals: improvement of the urban environment, new social infrastructures and services, social integration programs, economic activity promotion, and employability through professional training for the local unem- 
ployed population and specific groups (such as the long-term unemployed, women, and young people) (European Commission, 1994). In this regard, unemployment in Spain was a crucial public issue in the late 1980s and 1990s. Significant differences existed compared with the EU average, especially among the younger population. The unemployment rate among the active population up to 25 years old was 30 percent in Spain compared with 5 percent in the EU [39,40]. According to local projects portfolios, analyzed by the comparative urban portfolio analysis method [5], labour inclusion in targeted neighbourhoods, especially among young people, was a central objective of the integrated initiatives designed in the URBAN local projects.

With regard to this objective, the policy theory underlying the URBAN projects in Spain is similar to other place-based initiatives focused on socio-economically disadvantaged urban areas. These initiatives combine actions oriented toward improving the labour market supply and demand sides [41]. Some of them try to encourage employment opportunities through inducement policy tools (economic or other) to alter the pay-off of decisions to improve or initiate economic activity in the neighbourhood (e.g., financial aid, improvement of premises, training in new technologies to improve commercialisation, etc.). Projects also include actions that attempt to increase labour inclusion by using training policy tools to enhance professional skills (e.g., information and advice about job opportunities and training courses).

Moreover, the two causal processes are set as complementary. Support for economic activity is a facilitation policy tool for residents' labour market inclusion; it is commonly presented in local project portfolios as an instrument to increase economic activity and employment in a neighbourhood. Specifically, this policy option means that the first should produce a contextual effect that encourages achieving the second. It should generate more employment opportunities for residents, who simultaneously improve their employability by acquiring professional skills and better information about the labour market; this is a common strategy in initiatives funded by the EU to increase youth employment [42]. For example, increasing or attracting economic activities in a neighbourhood will reduce displacement and the information costs in job-seeking processes, which are two mechanisms explaining unemployment in disadvantaged urban areas. Advice and information actions concerning existing and new job opportunities could also reduce these costs $[43,44]$.

Together with these complementary effects, other policy actions oriented at improving neighbourhoods' physical space and reducing social exclusion can facilitate the previous integral strategy. Urban space improvements-through planning regulations, infrastructure, and public space enhancements-can promote a more attractive environment for economic activities [45], increasing job opportunities for residents. Welfare services and sensitisation initiatives regarding lifestyles could improve residents' employability (for instance, health, educational, or social policy actions) [46].

Nevertheless, only the complementarity effect between economic support and employability policy actions is included in local portfolios. This effect also implicitly establishes two premises that could affect expected outcomes. On the one hand, this complementation supposes a match between skills acquired by residents in training policy actions and occupational requirements of new economic activities in the targeted neighbourhoods. However, projects do not set out mechanisms to ensure this match. On the other hand, this complementary effect assumes that the process being modified (job seeking and localisation business decisions) occurs on the neighbourhood scale: residents will mainly find jobs in new labour opportunities generated in the neighbourhood. However, new economic activities could attract the working population from other urban spaces, and neighbourhoods' residents will find suitable jobs according to their skills in other localisations (neighbourhoods or municipalities in the metropolitan area). Employment inclusion could increase independently from the business increase (more job opportunities) in targeted neighbourhoods. These implicit premises could explain mixed results of previous analyses about the impact of business support policy actions on employment in deprived neighbourhoods, from very few to no effects [46-49]. 


\subsection{Analysing Program Effects: Control Group Selection and Impact Method Analysis}

Census information and other data sources in Spain provide details at the census track level. Based on documents concerning local projects, the urban areas chosen as their targets were delimited as groups of adjacent census tracks in each city in 1991. No-chosen urban areas in each municipality were delimited as groups of adjacent census tracks with a similar socio-spatial vulnerability among them and a similar population size to the targeted ones. Urban areas had the same geographical area in 1991 and 2001 to allow comparison before and after the URBAN I implementation. In three cities, the census does not provide georeferences for census tracks in 1991; thus, in 26 cities, 568 comparable urban areas were delimited (542 no-chosen and 26 chosen as URBAN I territorial targets).

According to the program's eligibility criteria, targeted territories should be disadvantaged neighbourhoods in large cities: densely populated and with decaying urban fabric, declining economic activity, lack of infrastructure, high unemployment rates, and other social exclusion problems [28]. Based on available secondary data for 1991, four indicators measure these criteria: population density, houses in good condition, the density of business establishments per inhabitant, and the employment rate. The intentional selection bias established by the program means that, before implementation, differences should exist between the all of chosen and unchosen areas, according to the established eligibility criteria (see Table 3). Therefore, only the unchosen areas similar to targeted ones before program implementation should be selected as an appropriate control group to analyse the program's impact.

Table 3. Urban areas according to eligibility criteria (1991): selected and non-selected areas in participating cities. Mean (standard deviation).

\begin{tabular}{ccccc}
\hline Urban Areas & $\begin{array}{c}\text { Population Density } \\
\text { (Inhab./km } \mathbf{2}\end{array}$ & $\begin{array}{c}\text { Houses in Good } \\
\text { Condition } \\
\mathbf{( \% )}\end{array}$ & $\begin{array}{c}\text { Business Density } \\
\text { (Companies per 1000 } \\
\text { Inhabitants) }\end{array}$ & $\begin{array}{c}\text { Employment Rate } \\
\mathbf{( \% )}\end{array}$ \\
\hline Non-selected & $18,659.490$ & 83.896 & 6.115 & 81.204 \\
$(n=542)$ & $(16,355.711)$ & $(10.942)$ & $(7.4584)$ & $(6.198)$ \\
Selected & $15,164.347$ & 70.149 & 8.362 & 77.412 \\
$(n=26)$ & $(13,176.650)$ & $(17.634)$ & $(8.471)$ & $(6.442)$ \\
Total & $18,499.501$ & 83.267 & 6.218 & 81.031 \\
Difference $(t$-test) & $(16,230.602)$ & $(11.671)$ & $(7.514)$ & $(6.254)$ \\
\hline
\end{tabular}

Sources: Spanish census and E-Informa. Housing in good condition is defined by the Spanish Census. ${ }^{*} p<0.05^{* *} p<0.005^{* * *} p<0.001$.

Experimental and control groups were selected by performing propensity scores and Nearest Neighbor. Propensity scores were estimated by applying logistic regression models, including the presence or absence of interventions as the dependent variable and eligibilitycriteria in 1991 as the independent variables. Due to the substantial difference in the number of targeted and non-targeted areas, we used a 1:5 ratio in the matching process (caliper equal to 0 ). Experimental and control groups only incorporate those that fall within the common support area $[50,51]$. Propensity score matching was performed using the $\mathrm{R}$ module in SPSS software [52]. There were no significant differences in covariates between the experimental and control groups (standardized differences $<25 \%$ ). The explanatory capacity of regression models using matched cases was also lower than the same models including all urban areas. The urban areas selected as experimental and control groups through propensity score matching were similar according to the eligibility criteria in 1991 (Table 4). 
Table 4. Eligibility criteria and residential stability in experimental and control groups (1991).

\begin{tabular}{ccccc}
\hline Urban Areas & $\begin{array}{c}\text { Population Density } \\
(\text { Inhab./km })\end{array}$ & $\begin{array}{c}\text { Houses in Good } \\
\text { Condition } \\
(\mathbf{\%})\end{array}$ & $\begin{array}{c}\text { Business Density } \\
\text { (Companies by 1000 } \\
\text { Inhabitants) }\end{array}$ & $\begin{array}{c}\text { Employment Rate } \\
\mathbf{( \% )}\end{array}$ \\
\hline Control group & $16,052.857$ & 74.935 & 7.385 & 79.025 \\
$(n=115)$ & $(15,528.010)$ & $(12.351)$ & $(8.609)$ & $(7.426)$ \\
Experimental group $(n=23)$ & $16,138.452$ & 74.636 & $(8.882$ & 78.962 \\
Total $(n=138)$ & $(13,618.488)$ & $(12.388)$ & 7.634 & $(4.564)$ \\
Difference $(t$-test) & $16,067.122$ & $(12.312)$ & $(8.630)$ & 79.014 \\
\hline
\end{tabular}

The program's impact was analysed by computing effect sizes, specifically the differences in change trends for the experimental and control groups between the pre and post-implementation periods (1991 and 2001). Specifically, we used the dRM indicator suggested by Morris and DeShon to analyse effect sizes in repeated measurements with control group designs. This indicator measures an improvement in performance among the experimental group regarding the outcomes of policy actions: business density and unemployment rate [53]. Cohen's r effect size assesses the complementarity effects between these policy actions. This indicator measures the differences in correlations between changes in business density and employment rates between 1991 and 2001 in the experimental and control groups [54]. The results presented the magnitude of effect sizes and confidence intervals (CI 90\%) to provide information about their estimation precision $[55,56]$.

\subsection{Controlling for Policy Exposure: Stayers and Age Cohorts}

The program's impact on employment will depend on residents' contextual and specific exposure to policy actions implemented in the targeted neighbourhoods. The impact of place-based policies could be affected by mobility across urban areas due to new residents attracted during the program's implementation (incomers) and residents who move to other urban areas (out-movers). Specifically, these programs could promote a "moving escalator effect," whereby residents, especially young people, improve their socio-economic conditions and then move to a better neighbourhood [57]. Therefore, impact analyses should also aim to control contextual policy exposure due to urban mobility. Similarly, analyses should include specific policy exposure according to the targets established for each policy action because causal processes are designed to affect specific residents rather than all of them [58].

There is no individual longitudinal data on residential mobility between 1991 and 2001 or data about individual beneficiaries of policy actions. Therefore, we used two proxies to control contextual policy exposure to the program and specific exposure to employability policy actions. The post-intervention measurement only included individuals who resided in the same household between 1991 and 2001; therefore, the people most likely to have been exposed to the program were "stayers" (permanent residents) in the urban area during the project's implementation. This analysis can approximate the program's effects, discounting any possible influence linked to incomers. However, this strategy has two potential limitations. First, we assumed that permanent residents in 2001 were representative of all residents in 1991. Second, the analyses did not measure the potential "moving escalator effect" (out-movers who were able to find employment and relocated to other areas). Therefore, this strategy was conservative; it could underestimate the impact of a program because it did not include the potential positive effect on those residents who moved to another neighbourhood.

Changes within four 10-year cohorts aged 15 to 65 between 1991 and 2001 were analysed as a proxy of specific policy exposure. We compared the employment rate in an age group in 1991 with the corresponding age group of permanent residents in 2001. Although employability actions are usually focused on unemployed people in a 
neighbourhood, projects also establish specific target populations, especially young people and the older long-term unemployed. The evaluative reports for projects do not provide information about the type of people who attended training activities (their beneficiaries), but other evidence for Spain shows that young people have a greater propensity to attend these activities than their older counterparts [39].

The use of aggregate (ecological) data and our proxies to policy exposure-instead of individual longitudinal data distinguishing between beneficiaries and non-beneficiaries of policy actions-could underestimate evidence about a program's impact. Therefore, attention should be paid to this issue when analysing the effect size. In fact, analysis based on aggregate data could be one reason for the moderate effects found in previous studies about similar place-based policies [59-61]. Despite this limitation, our analysis compared targeted neighbourhoods with a control group to reduce the attribution gap in analysing these urban policies [62] and provided proxies for contextual and specific policy exposure instead of the whole neighbourhood population.

\section{Results and Discussion}

The employment rate increased by 3.5 points in experimental and control areas, a similar trend to that in Spain as a whole during this period [63,64]. Nevertheless, differences existed according to age cohorts (Table 5). The youngest (15-25 years old in 1991) showed the highest increase (18 points). This difference is a common trend in labour market analyses because many members of this cohort change from an inactive to an active situation by entering the labour market for the first time $[65,66]$. The change is smaller in older cohorts where there are already a greater number of economically active people, except in the group aged $26-35$ years (aged 36 to 45 years in 2001) with a difference of six points.

Table 5. Employment rates in experimental and control groups (1991-2001). Mean (Standard Deviation).

\begin{tabular}{|c|c|c|c|c|c|c|c|c|c|}
\hline & \multicolumn{3}{|c|}{$\begin{array}{c}1991 \\
\text { (All Residents) }\end{array}$} & \multicolumn{3}{|c|}{$\begin{array}{c}2001 \\
\text { (Permanent Residents) }\end{array}$} & \multicolumn{3}{|c|}{$\begin{array}{l}\text { Differences } \\
\text { 1991-2001 }\end{array}$} \\
\hline & Exp. & Control & Total & Exp. & Control & Total & Exp. & Control & Total \\
\hline Total & $\begin{array}{l}78.962 \\
(4.564)\end{array}$ & $\begin{array}{l}79.025 \\
(7.426)\end{array}$ & $\begin{array}{l}79.014 \\
(7.017)\end{array}$ & $\begin{array}{l}82.677 \\
(4.823)\end{array}$ & $\begin{array}{l}82.438 \\
(6.829)\end{array}$ & $\begin{array}{l}82.478 \\
(6.523)\end{array}$ & $\begin{array}{l}3.715 \\
(2.486)\end{array}$ & $\begin{array}{c}3.413 \\
(3.873)\end{array}$ & $\begin{array}{c}3.464 \\
(3.673)\end{array}$ \\
\hline $\begin{array}{c}\text { 15-25 (1991) to } 25-35 \\
\text { (2001) }\end{array}$ & $\begin{array}{l}61.057 \\
(8.409)\end{array}$ & $\begin{array}{c}63.318 \\
(10.129)\end{array}$ & $\begin{array}{l}62.941 \\
(9.872)\end{array}$ & $\begin{array}{l}80.657 \\
(5.655)\end{array}$ & $\begin{array}{l}81.055 \\
(6.935)\end{array}$ & $\begin{array}{l}80.989 \\
(6.722) \\
\end{array}$ & $\begin{array}{l}19.601 \\
(5.618)\end{array}$ & $\begin{array}{l}17.737 \\
(6.363) \\
\end{array}$ & $\begin{array}{l}18.048 \\
(6.264)\end{array}$ \\
\hline $\begin{array}{c}26-35 \text { (1991) to } 36-45 \\
\text { (2001) }\end{array}$ & $\begin{array}{l}78.093 \\
(4.679)\end{array}$ & $\begin{array}{l}78.694 \\
(6.802)\end{array}$ & $\begin{array}{l}78.594 \\
(6.486) \\
\end{array}$ & $\begin{array}{l}85.340 \\
(3.889)\end{array}$ & $\begin{array}{l}84.729 \\
(6.409)\end{array}$ & $\begin{array}{l}84.831 \\
(6.054) \\
\end{array}$ & $\begin{array}{l}7.247 \\
(2.903)\end{array}$ & $\begin{array}{c}6.036 \\
(4.001) \\
\end{array}$ & $\begin{array}{c}6.237 \\
(3.857) \\
\end{array}$ \\
\hline $\begin{array}{c}\text { 36-45 (1991) to } 46-55 \\
\text { (2001) }\end{array}$ & $\begin{array}{l}87.147 \\
(2.887)\end{array}$ & $\begin{array}{l}86.725 \\
(5.875)\end{array}$ & $\begin{array}{l}86.795 \\
(5.485)\end{array}$ & $\begin{array}{l}88.373 \\
(3.622)\end{array}$ & $\begin{array}{l}87.625 \\
(5.694)\end{array}$ & $\begin{array}{l}87.750 \\
(5.401) \\
\end{array}$ & $\begin{array}{l}1.225 \\
(2.107)\end{array}$ & $\begin{array}{c}0.901 \\
(3.133) \\
\end{array}$ & $\begin{array}{c}0.955 \\
(2.983)\end{array}$ \\
\hline $\begin{array}{c}46-55 \text { (1991) to 56-65 } \\
\text { (2001) }\end{array}$ & $\begin{array}{l}88.558 \\
(3.283)\end{array}$ & $\begin{array}{l}88.115 \\
(5.634)\end{array}$ & $\begin{array}{l}88.189 \\
(5.307)\end{array}$ & $\begin{array}{l}86.987 \\
(3.862)\end{array}$ & $\begin{array}{l}85.997 \\
(5.711)\end{array}$ & $\begin{array}{l}86.162 \\
(5.448)\end{array}$ & $\begin{array}{l}-1.571 \\
(2.483)\end{array}$ & $\begin{array}{l}-2.118 \\
(4.096)\end{array}$ & $\begin{array}{l}-2.027 \\
(3.872)\end{array}$ \\
\hline
\end{tabular}

Source: Spanish Census. Experimental group: 23 areas; Control group: 115 areas.

The effect sizes for the unemployment rate showed a similar change pattern in the experimental and control areas; the confidence interval range indicated that the differences between them were not significant ( $\mathrm{dRM}=0.022$; C190: $-0.211 ; 0.374)$. Nevertheless, differences existed according to our proxy for employability policy exposure (Figure 1 and Table A2 in the Appendix A). Changes for those aged 36-45 years and 46-55 years in 1991 were similar in the experimental and control groups (dRM equal to 0.108 and 0.116 , respectively; $\mathrm{CI}$ crossed the zero value). Instead, differences existed among the youngest cohorts, aged 16-25 and 26-35 in 1991, indicating a low effect of the program ( $\mathrm{dRM}=0.298$; C190: 0.005-0.591). Residential mobility was particularly apparent among these cohorts, and this may be related to the above-mentioned "moving escalator effect." Nevertheless, the rate of out-movers in these age cohorts was equal in the experimental and control 
groups (see Table A1 in the Appendix A). Therefore, the URBAN I initiative seems to have promoted better labour market inclusion among the youngest cohorts in the targeted areas.

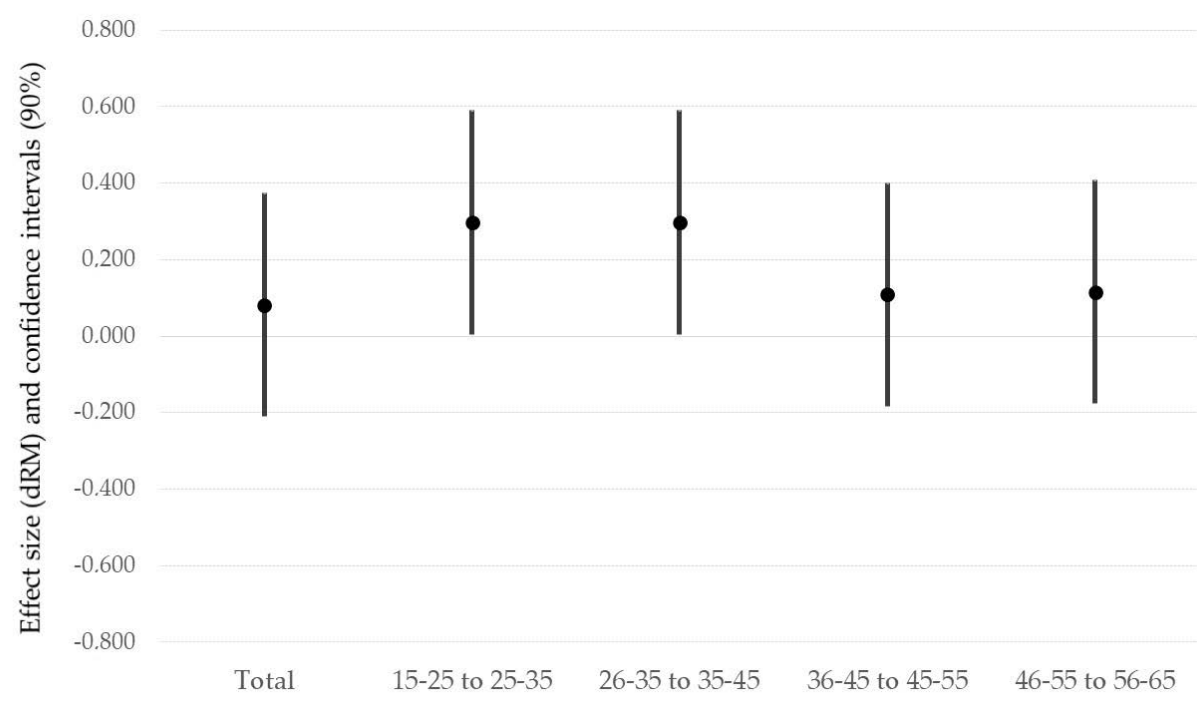

Figure 1. URBAN I impact on employment (1991-2001).

Young people are a central target of actions regarding employability training in Spanish URBAN projects, and they have a greater tendency to attend this type of training course than older age cohorts. Accordingly, previous results showed a moderate effect of these policy actions with regard to younger age cohorts. However, according to URBAN I policy theory, this result could also be related to the outcomes of economic support policy actions. Business density increased in both the experimental and control areas during a cycle of economic growth in Spain between 1991 and 2001 (a difference of 19 points, see Table 6); however, effect size showed this positive change was greater in the experimental than in the control areas $(\mathrm{dRM}=0.451 ; \mathrm{CI} 90: 0.157-0.746)$. Therefore, the program increased economic activity - and thereby employment opportunities—in the targeted neighbourhoods.

Table 6. Business density in experimental and control groups (1991-2001). Mean (Standard Deviation).

\begin{tabular}{cccc}
\hline & $\mathbf{1 9 9 1}$ & $\mathbf{2 0 0 1}$ & $\begin{array}{c}\text { Difference } \\
\mathbf{2 0 0 1 - 1 9 9 1}\end{array}$ \\
\hline \multirow{2}{*}{ Control } & 7.385 & 25.047 & 17.662 \\
& $(8.609)$ & $(22.916)$ & $(14.653)$ \\
Experimental & 8.820 & 33.619 & 24.735 \\
& $(8.821)$ & $(28.375)$ & $(20.164)$ \\
Total & 7.634 & 26.475 & 18.841 \\
& $(8.630)$ & $(24.011)$ & $(15.841)$ \\
\hline
\end{tabular}

Source: E-Informa. Experimental group: 23 areas; control group: 115 areas.

Correlations between the change in business density and the change in employment rates are nevertheless low, although higher in the experimental group than in the control group (see Table A3 in the Appendix A). For the total active population, the effect sizes showed the relationship between changes in business density and the employment rate was slightly higher in targeted neighbourhoods $(r=0.231$; CI90: $-0.062 ; 0.524)$, although this effect concentrated on residents aged 26-35 in 1991 ( $r=0.265$; C190: -0.028 ; 0.558). However, the confidence intervals prevented solid conclusions about any facilitation effect of increased job opportunities on the labour market inclusion; the complementary link between causal processes promoted these two outcomes (Figure 2). 


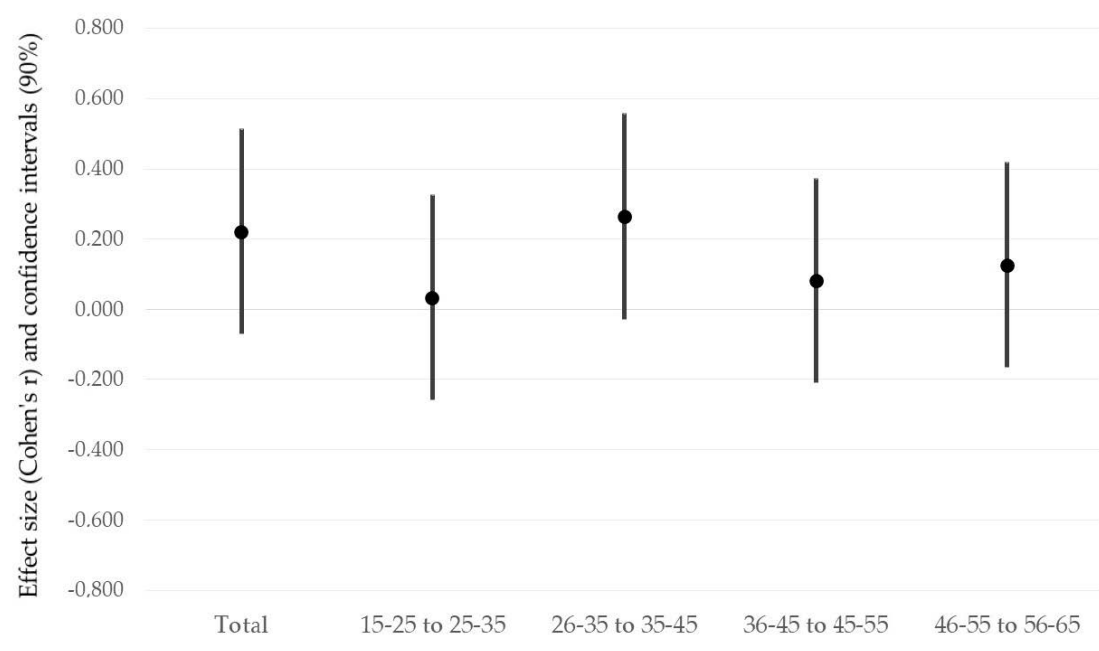

Figure 2. The relationship between changes in business density and employment rate. Difference between correlations in experimental and control groups.

Analyses showed the achievement of the economic activity goal and, to some extent, the employment goal among the youngest population, though the complementary effect between them was less evident. The impact on business density was not associated with a significant increase in employment rates in experimental neighbourhoods. This result could be explained by displacement effects, as analyses of other similar initiatives showed. Spillover effects could promote more economic activity and employment in surrounding urban areas because these could offer a more suitable location in the city than in the targeted areas $[67,68]$. Furthermore, residents from surrounding areas could take up the new jobs created in targeted areas [69,70]. Therefore, economic activity could increase in targeted neighbourhoods without improvements in the residents' employment and quality of life [71].

The program's theory also implicitly supports two interrelated premises regarding the complementary effect between increasing economic activity and residents' employment. First, this complementary effect means residents will seek and find jobs preferentially in their neighbourhoods. Second, a match exists between the occupational structure of increasing job opportunities and the new professional skills acquired. However, job seeking and suitable labour options have a broad urban scale similar to business locations and residential choices. Improving the work skills among residents does not imply that they will find a job in their neighbourhoods. More, or more suitable, job opportunities according to their new labour skills could exist in other neighbourhoods or other municipalities in the metropolitan area. The opposite could apply to residents in other urban areas regarding the type of new job opportunities in targeted locations. The absence of complementary effects could be due to the contrast between these two implicit premises in the program theory and the multi-scalar processes surrounding job-seeking, business location, and residential decisions, as well as other processes explaining neighbourhood change.

\section{Integral and Sustainable Urban Development Strategies: Methodological Challenges and Policy Theories Enhancement}

Urban initiatives and programs in the EU Cohesion Policy framework have adopted an integral policy strategy. These initiatives attempt to produce sustainable urban development through local policy mixes based on integration among various policy tools, using their causal processes to attain their outcomes. Our analysis regarding the URBAN I Initiative in Spain showed positive impacts on two policy objectives: economic activity and employment for the youngest age cohorts. Nevertheless, the results did not provide robust evidence about the complementary effect behind the integral strategy for increasing employment. 
This evaluative exercise had some limitations that should be noted. First, our approximation of policy exposure using aggregate data for age cohorts at the neighbourhood level implied a conservative strategy that could have underestimated the program's effects. As mentioned above, evaluations made for similar policies using aggregate data also showed moderate or even no effects. Our results showed the program accomplished, to some extent, some of its goals, but better data would be required in order to provide more robust evidence. Second, the post-intervention measurement was made very close to the end of the program. This might have limited the possibility of detecting its impact, especially regarding actions based on "capacity buildings tools" (such as employability ones) where the effects are more evident in the medium or long term [72]. Lastly, although we assessed the program's theory, differences among local projects could exist according to the importance of different policy actions and specific differences among their territorial targets [25]. These differences could promote opposite effects on outcomes, explaining the program's low impact on employment (as a compositional effect among different portfolios in different urban areas). Therefore, the heterogeneity of program impacts should also be studied.

Some of these limitations could only be avoided by improving existing data, allowing for the analysis of individual longitudinal measurements for residents and their exposure to a program's policy actions, e.g., data about residents labour situation before and after interventions, their exposure to specific policy actions, and their jobs localisation. Therefore, to provide better answers about the effects of such initiatives, the institutions promoting them should encourage the production of appropriate data to address these methodological challenges.

Despite these methodological issues, the results also suggested improvements regarding the policy theory behind the analysed integral policy strategy. This strategy neglected and therefore should incorporate the multi-scaler character of urban processes. First, displacement and spillover effects between neighbourhoods or municipalities in metropolitan areas could undermine the expected impact of economic development actions on increasing employment among the targeted residents. Local labour markets, and business location decisions, have a broader scale than specific urban areas (neighbourhoods). Second, a mismatch between the occupational structure of new job opportunities and acquired labour skills could undermine the expected complementary effects of business inducements on training for unemployed residents. In this situation, economic activity in targeted spaces could attract workers from other territories with the required skills, and residents would need to expand their job-seeking activity outside targeted areas to find suitable work for their occupational skills. A better match does not guarantee that companies in targeted areas will hire residents; this also depends on employers' recruitment methods and preferences [73]. However, a better match would at least increase labour market inclusion opportunities in a neighbourhood. Despite the importance of these displacement and mismatch effects to explain inclusion in the labour market [73], the program and urban portfolios analysed did not mention them. Therefore, integral strategies should include policy actions to prevent these potential adverse effects, or at least to be aware of them.

As indicated before, EU urban initiatives have changed the scale of targeted territories, including functional urban areas (the EU proxy for metropolitan areas) together with the previous target, which was focused on infra-municipal areas (neighbourhoods). Nevertheless, changing the scale of targeted territories would not address the need to improve the integral policy theory that underlies the intervention logic of local policy mixes, the specification of targets (policy exposure), and the causal process promoted by policy tools and their complementarity. The scale of territorial targets and the scale of urban processes that policy tries to modify may not match. Policy design of integral urban initiatives should incorporate this aspect to improve policy theory regarding their established expected outcomes.

Previous results show that low impact on the total population may be explained by composition effects resulting from different target groups, their specific dynamics in labour 
market integration, and their exposure to policy actions. Although it may not be evident for the population as a whole, effects may exist for some targets and specific groups. Similar differences among groups of residents according to other social traits may occur with regard to other policy actions. Compositional effects could arise from assuming that the same policy theory (causal process) has a similar impact in different groups.

The analysed program appeared to produce the expected changes to economic activity and employment inclusion among specific targeted groups as a summative result of goal achievement in different policy sectors. However, it remains less clear that this is a consequence of policy integration as complementary effects between different policy tools and their causal processes, at least in the case analysed and with the research methods used in this article. Urban policies with multiple objectives will promote sustainable urban development achievements through actions across different policy sectors, but this does not mean that such achievements result from the integral policy strategies included in policy mixes. As mentioned before, the comprehensiveness of goals and intervention logic are two different dimensions of integral policy strategies that do not have to take place simultaneously in all cases. Therefore, further research is needed to understand the policy theory behind the integral strategy in urban policy mixes, their dimensions, and their effectiveness regarding sustainable urban development goals. This article tried to do this exercise by analysing an exemplar program promoted by the EU and its results in the Spanish case.

Funding: This research was developed in the framework of the Jean Monnet Chair in European Urban Policies (EUrPol), supported by the European Commission (Ref. Project: 612051-EPP-1-2019-1-ESEPPJMO-CHAIR). Data were collected in the framework of the URBAN-IMPACTS project financed by the MINECO-Spanish Government and the ERDF-European Union (Grant No. CSO2015-70048-R).

Institutional Review Board Statement: Not Applicable.

Informed Consent Statement: Not applicable.

Data Availability Statement: Restrictions apply to the availability of these data. Data were obtained from the Instituto Nacional de Estadística through a specific agreement. This agreement limit data sharing.

Acknowledgments: We would like to express our gratitude for access to the documentation of local projects provided by the Spanish national authority in charge of the evaluated program: Dirección General de Fondos Comunitarios, Ministerio de Hacienda, Spanish Government.

Conflicts of Interest: The authors declare no conflict of interest. The European Commission's support of this publication through the Jean Monnet Chain in European Urban Policies (Ref. Project: 612051EPP-1-2019-1-ES-EPPJMO-CHAIR) does not constitute an endorsement of the contents, which reflect the views only of the authors. The Commission cannot be held responsible for any use that may be made of the information contained therein.

\section{Appendix A}

Table A1. Residential stability. Percentage of permanent residents out of the total residents in 2001.

\begin{tabular}{|c|c|c|c|c|c|c|c|c|}
\hline & & \multicolumn{2}{|c|}{ Experimental } & \multicolumn{2}{|c|}{ Control } & \multicolumn{2}{|c|}{ Total } & \multirow[t]{2}{*}{ Difference (1) } \\
\hline & & Mean & Std. Dev & Mean & Std. Dev & Mean & Std. Dev & \\
\hline Total & & 60.051 & 6.977 & 60.244 & 11.597 & 60.212 & 10.943 & 0.193 \\
\hline \multirow{5}{*}{ Age groups } & $26-35$ & 62.294 & 8.622 & 62.975 & 12.186 & 62.862 & 11.644 & 0.681 \\
\hline & $36-45$ & 42.415 & 10.041 & 43.120 & 13.713 & 43.003 & 13.143 & 0.706 \\
\hline & $46-55$ & 49.939 & 8.037 & 50.377 & 12.642 & 50.304 & 11.975 & 0.437 \\
\hline & $46-55$ & 69.332 & 7.922 & 69.566 & 11.713 & 69.527 & 11.147 & 0.234 \\
\hline & $56-65$ & 78.427 & 6.235 & 79.714 & 10.467 & 79.499 & 9.882 & 1.287 \\
\hline
\end{tabular}

Source: Spanish Census. 1 According to the $t$-test, all differences are not significant for $p<0.001$. 
Table A2. The impact of URBAN I on unemployment rates and business density. Effect size (dRM) and confidence intervals (CI 90\%).

\begin{tabular}{ccccc}
\hline & dRM & CI (90\%) & \\
\hline Employment rate & Total & 0.082 & -0.211 & 0.005 \\
& $15-25(1991)$ to 25-35 (2001) & 0.298 & 0.005 & 0.592 \\
& $26-35(1991)$ to 35-45 (2001) & 0.298 & -0.184 & 0.591 \\
Business density & 36-45 (1991) to 45-55(2001) & 0.108 & -0.177 & 0.401 \\
& $46-55(1991)$ to 56-65 (2001) & 0.116 & 0.457 & 0.746 \\
\hline
\end{tabular}

Table A3. Changes in business density and employment rate. Correlations, effect size (Cohen's r), and confidence intervals (CI 90\%).

\begin{tabular}{cccccc}
\hline & \multicolumn{2}{c}{ Correlations } & \multicolumn{2}{c}{ Cohen's r } \\
\cline { 2 - 6 } & Experimental & Control & r & \multicolumn{2}{c}{ CI (90\%) } \\
\hline Total & 0.108 & -0.112 & 0.231 & -0.062 & 0.524 \\
15-25 (1991) to 25-35 (2001) & 0.050 & 0.016 & 0.034 & -0.258 & 0.326 \\
26-35 (1991) to 35-45 (2001) & 0.257 & -0.002 & 0.265 & -0.028 & 0.558 \\
36-45 (1991) to 45-55 (2001) & 0.050 & -0.032 & 0.082 & -0.210 & 0.374 \\
46-55 (1991) to 56-65 (2001) & 0.133 & 0.008 & 0.126 & -0.167 & 0.416 \\
\hline
\end{tabular}

\section{References}

1. Cejudo, G.M.; Michel, C.L. Addressing fragmented government action: Coordination, coherence, and integration. Policy Sci. 2017, 50, 745-767. [CrossRef]

2. Howlett, M. The criteria for effective policy design: Character and context in policy instrument choice. J. Asian Public Policy 2017, 11, 245-266. [CrossRef]

3. Navarro, C.J.; Rodríguez-García, M.J. Urban policies as multi-level policy mixes. The comparative urban portfolio analysis to study the strategies of integral urban development initiatives. Cities 2020, 102, 102716. [CrossRef]

4. Rogers, P.J.; Hasci, T.A.; Petrosino, A.; Huebner, H.E. Program Theory in Evaluation, New Directions for Evaluation; Jossey-Bass: San Francisco, CA, USA, 2000.

5. Schneider, A.; Ingram, H. Behavioral assumptions of policy tools. J. Polit. 1990, 52, 510-529. [CrossRef]

6. Howlett, M. Governance modes, policy regimes and operational plans: A multi-level nested model of policy instrument choice and policy design. Policy Sci. 2009, 42, 73-89. [CrossRef]

7. Carmon, N. Neighborhood regeneration: The state of the art. J. Plan. Educ. Res. 1997, 17, 131-144. [CrossRef]

8. Van Gent, W.P.; Musterd, S.; Ostendorf, W. Disentangling neighbourhood problems: Area-based interventions in Western European cities. Urban Res. Pr. 2009, 2, 53-67. [CrossRef]

9. UN-Habitat. The New Urban Agenda. 2017. Available online: http://habitat3.org/the-newurban-agenda/ (accessed on 28 April 2011).

10. Camagni, R. Sustainable urban development: Definition and reasons for a research programme. Int. J. Environ. Pollut. 1998, 10, 6. [CrossRef]

11. Zheng, H.W.; Shen, Q.; Wang, H. A review of recent studies on sustainable urban renewal. Habitat Int. 2014, 41, 272-279. [CrossRef]

12. Blank, R.M. Poverty, policy, and place: How poverty and policies to alleviate poverty are shaped by local characteristics. Int. Reg. Sci. Rev. 2005, 28, 441-464. [CrossRef]

13. Powell, M.; Boyne, G.; Ashworth, R. Towards a geography of people poverty and place poverty. Policy Polit. 2001, 29, 243-258. [CrossRef]

14. Greenbaum, R.T.; Bondonio, D. Losing focus: A comparative evaluation of spatially targeted economic revitalisation programmes in the US and the EU. Reg. Stud. 2004, 38, 319-334. [CrossRef]

15. Greig, A.; El-Haram, M.; Horner, M. Using deprivation indices in regeneration: Does the response match the diagnosis? Cities 2010, 27, 476-482. [CrossRef]

16. Shiels, C.; Baker, D.; Barrow, S. "How accurately does regeneration target local need?" Targeting deprived communities in the UK. Int. J. Public Sect. Manag. 2013, 26, 203-215. [CrossRef]

17. Tosun, J.; Lang, L. Policy integration: Mapping the different concepts. Policy Stud. 2017, 38, 553-570. [CrossRef]

18. Trein, P.; Meyer, I.; Maggetti, M. The integration and coordination of public policies: A systematic comparative review. J. Comp. Policy Anal. Res. Pr. 2019, 21, 332-349. [CrossRef]

19. Burstein, P. Policy domains: Organisation, culture, and policy outcomes. Annu. Rev. Sociol. 1991, 17, 327-350. [CrossRef] 
20. Navarro, C.J. Governing the entertainment machine. In The Politics of Urban Cultural Policy; Godrach, C., Silver, D., Eds.; Routledge: London, UK, 2013; pp. 221-236.

21. Navarro, C.J.; Rodríguez-García, M.J. Models of local governing coalitions. Urban Geogr. 2015, 36, 1149-1168. [CrossRef]

22. Candel, J.; Briesbroke, R. Toward a processual understanding of policy integration. Policy Sci. 2016, 49, 211-231. [CrossRef]

23. Capano, G.; Howlett, M. The knowns and unknowns of policy instrument analysis: Policy tools and the current agenda on policy mixes. SAGE Open 2020, 10, 1-13. [CrossRef]

24. Fioretti, C.; Pertoldi, M.; Busti, M.; Van Heerden, D. Handbook of Sustainable Urban Development Strategies; Publications Office of the European Union: Luxembourg, 2020.

25. Navarro, C.J. Políticas de regeneración urbana en España en el marco de iniciativas de la Unión Europea. Papers 2020, 63, 68-81.

26. Medeiros, E. Territorial Cohesion: An EU concept. Eur. J. Spat. Dev. 2016, 60, 1-30.

27. Medeiros, E.; Van Der Zwet, A. Evaluating Integrated Sustainable Urban Development Strategies: A methodological framework applied in Portugal. Eur. Plan. Stud. 2019, 28, 563-582. [CrossRef]

28. European Commission. Notice to the Member States Laying down Guidelines for Operational Programmes which Member States Are Invited to Establish in the Framework of a Community Initiative Concerning Urban Areas (Urban); European Commission: Brussels, Belgium, 1994.

29. European Commission. Guidelines for a Community Initiative Concerning Economic and Social Regeneration of Cities and of Neighbourhoods in Crisis in Order to Promote Sustainable Urban Development (URBAN II) (2000/C 141/04); European Commission: Brussels, Belgium, 2000.

30. Tosic, I. Integrated territorial investment: A missed opportunity? In EU Cohesion Policy; Bachtler, J., Berkowitz, P., Hardy, S., Muravska, T., Eds.; Routledge: London, UK, 2020; pp. 284-298.

31. Navarro-Yáñez, C.J.; Rodríguez-García, M.-J.; Guerrero-Mayo, M.J. Evaluating the quality of urban development plans promoted by the European Union: The URBAN and URBANA initiatives in Spain (1994-2013). Soc. Indic. Res. 2019, 149, 215-237. [CrossRef]

32. Armstrong, H.; Wells, P. Structural funds and the evaluation of community economic development initiatives in the UK: A critical perspective. Reg. Stud. 2006, 40, 259-272. [CrossRef]

33. ESPON. Indicators for Integrated Territorial and Urban Development, Luxembourg, ESPON EGTC. 2018. Available online: https://www.espon.eu/sites/default/ files/attachments/Working\%20Paper\%20Indicators\%20for\%20integrated\%20 development.pdf (accessed on 3 April 2021).

34. European Commission. Ex-Post Evaluation. Urban Community Initiative; European Union: Brussels, Belgium, 2003.

35. European Commission. Ex-Post Evaluation of Cohesion Policy programmes 2000-2006: The URBAN Community Initiative; European Union: Brussels, Belgium, 2010.

36. European Commission. Ex Post Evaluation of Urban Development and Social Infrastructures; European Union: Brussels, Belgium, 2016.

37. Guyadeen, D.; Seasons, M. Evaluation theory and practice: Comparing program evaluation and evaluation in planning. J. Plan. Educ. Res. 2018, 38, 98-110. [CrossRef]

38. Candel, J. Holy Grail or inflated expectations? The success and failure of integrated policy strategies. Policy Stud. 2017, 38, 519-552. [CrossRef]

39. García, J.R. Youth Unemployment in Spain: Causes and Solutions; BBVA Working Papers; BBVA Bank: Bilbao, Spain, 2011.

40. Cueto, B.; Martín-Román, Á.; Moral, A.; Mínguez, A.M. Youth employment in the Iberian countries. In European Youth Labour Markets; Springer Science and Business Media: Berlin/Heidelberg, Germany, 2017; pp. 27-43.

41. Chaudhary, N.; Potter, J. Evaluation of the local employment impacts of enterprise zones: A critique. Urban Stud. 2018, 56, 2112-2159. [CrossRef]

42. Tosun, J.; Speckesser, S.; Jensen, C.; O’Reilly, J. The absorption of Structural and Investment Funds and youth unemployment. In EU Cohesion Policy; Bachtler, J., Berkowitz, P., Hardy, S., Muravska, J., Eds.; Routledge: London, UK, 2020; pp. 151-168.

43. Gibillon, L.; Selod, H.; Zanou, Y. The mechanisms of spatial mismatch. Urban Stud. 2007, 44, 2401-2427. [CrossRef]

44. Chapple, K. Overcoming mismatch: Beyond dispersal, mobility, and development strategies. J. Am. Plan. Assoc. 2006, 72, 322-336. [CrossRef]

45. Servillo, L.; Atkinson, R.; Russo, A.P. Territorial attractiveness in EU urban and spatial policy: A critical review and future research agenda. Eur. Urban Reg. Stud. 2012, 19, 349-365. [CrossRef]

46. Kearns, A.; Manson, P. Entering and leaving employment in deprived neighbourhoods undergoing area regeneration. Local Econ. 2018, 33, 537-561. [CrossRef]

47. Bondonio, D.; Engberg, J. Enterprise zones and local employment: Evidence from the states' programs. Reg. Sci. Urban Econ. 2000, 30, 519-549. [CrossRef]

48. Bollinger, C.R.; Ihlanfeldt, K.R. The intraurban spatial distribution of employment: Which government interventions make a difference? J. Urban Econ. 2003, 53, 396-412. [CrossRef]

49. Albanese, G.; Ciani, E.; De Blasio, G. Anything new in town? The local effects of urban regeneration policies in Italy. Reg. Sci. Urban Econ. 2021, 86, 103623. [CrossRef]

50. Caliendo, M.; Kopeinig, S. Some practical guidance for the implementation of propensity score matching. J. Econ. Surv. 2008, 22, 31-72. [CrossRef]

51. Li, M. Using the propensity score method to estimate causal effects: A review and practical guide. Organ. Res. Methods 2013, 16, 188-226. [CrossRef] 
52. Thoemmes, F. Propensity score matching in SPSS. arXiv 2012, arXiv:1201.6385.

53. Morris, S.B.; DeShon, R.P. Combining effect size in meta-analysis with repeated measures and independent-groups designs. Physiol. Methods 2002, 7, 105-125. [CrossRef] [PubMed]

54. Cohen, J. Statistical Power Analysis for the Behavioral Sciences, 2nd ed.; Lawrence Erlbaum: Mahwah, NJ, USA, 1988.

55. Fritz, C.O.; Morris, P.E.; Richler, J.J. Effect size estimates: Current use, calculations, and interpretation. J. Exp. Psychol. Gen. 2012, 141, 2-18. [CrossRef] [PubMed]

56. Kramer, S.H.; Rosdenthal, R. Effect sizes and significance levels in small-sample research. In Statistical Strategies for Small Sample Research; Hoyle, R.H., Ed.; Sage: Thousand Oaks, CA, USA, 1999; pp. 60-81.

57. Cole, I.; Lawless, P.; Manning, J.; Wilson, I. The Moving Escalator; Department for Communities and Local Government: London, $\mathrm{UK}, 2007$.

58. Mavrot, C.; Hadorn, S.; Sager, F. Mapping the mix: Instruments, settings, and target groups in the study of policy mixes. Res. Policy 2019, 48, 103614. [CrossRef]

59. Laswell, P. Continuing dilemmas for are based urban regeneration: Evidence from the new deal for communities programme in England. People Place Policy 2007, 1, 14-21.

60. Thomson, H. A dose of realism for healthy urban policy: Lessons from area-based initiatives in the UK. J. Epidemiol. Community Health 2008, 62, 932-936. [CrossRef] [PubMed]

61. Rae, A. Learning from the past? A review of approaches to spatial targeting in urban policy. Plan. Theory Pr. 2011, 12, 331-348. [CrossRef]

62. Rossi, P.H. Evaluating community development programs: Problems and prospects. In Urban Problems and Community Development; Ferguson, R.F., Dickens, W.Y., Eds.; Brookings Institution Press: Washington, DC, USA, 1999; pp. 521-568.

63. Toharia, L. Employment patterns in Spain between 1970 and 2001. Int. J. Polit. Econ. 2000, 30, 82-98. [CrossRef]

64. Jiménez, J.; Pimentel, M.; Echevarría, M. España 2010: Mercado Laboral; Diez de Santos: Madrid, Spain, 2002.

65. Balleer, A.; Gomez-Salvador, R.; Turunen, J. Labour force participation across Europe: A cohort-based analysis. Empir. Econ. 2014, 46, 1385-1415. [CrossRef]

66. Roth, D.; Moffat, J. Cohort Size and Youth Unemployment in Europe: A Regional Analysis. Jt. Discuss. Pap. Ser. Econ. 2014, 40. Available online: http://www.uni-marburg.de/fb02/makro/forschung/magkspapers/index_html\%28magks\%29 (accessed on 3 April 2021).

67. Hanson, A.; Rohlin, S. Do spatially targeted redevelopment programs spivoller? Reg. Sci. Urban Econ. 2013, 43, 86-100. [CrossRef]

68. Givord, P.; Rathelot, R.; Sillard, P. Place-based tax exemptions and displacement effects: An evaluation of the Zones Franches Urbaines program. Reg. Sci. Urban Econ. 2013, 43, 151-163. [CrossRef]

69. Rhodes, J.; Brennan, A. Assessing the effect of area-based initiatives on local area outcomes: Some thoughts based on the national evaluation of the Single Regeneration Budget in England. Urban Stud. 2005, 42, 1919-1946. [CrossRef]

70. Busso, M.; Gregory, J.; Kline, P. Assessing the incidence and efficiency of a prominent place based policy. Am. Econ. Rev. 2013, 103, 897-947. [CrossRef]

71. Reynolds, C.L.; Rohlin, S. Do location-Based tax incentives improve quality of life and quality of business environment? J. Reg. Sci. 2014, 54, 1-32. [CrossRef]

72. McDonnel, L.; Elmore, R.F. Getting the job done: Alternative policy instruments. Educ. Eval. Policy Anal. 1987, 9, 1330-1562. [CrossRef]

73. Reingold, D.A. Inner-city firms and the employment problem of the urban poor: Are poor people really excluded from jobs located in their own neighborhoods? Econ. Dev. Q. 1999, 13, 291-306. [CrossRef] 